\title{
Chapter 5 \\ Ethnic and Linguistic Categories \\ in Quebec: Counting to Survive
}

\author{
Victor Piché
}

\subsection{Introduction}

For some time, statistical categories emanating from official data-producing agencies have been analyzed within their underlying ideological and historical contexts. ${ }^{1}$ In the introductory chapter, ${ }^{2}$ we have suggested a typology for the political use of ethnic categories. The case at hand - that of Quebec through the history of its ethnic and linguistic relationships in the Canadian context - illustrates the political and ideological role of ethnicity and language statistics in power relationships and survival strategies, especially with regards to the French-speaking minority group. The Canada/Quebec example is also interesting because it demonstrates that, within the same country, the use of these statistics may vary from one group to another. If, in the Canadian multicultural context, ethnicity-related census categories are currently legitimized by anti-discriminatory programmes, they also enable Francophone ${ }^{3}$ Quebecers to monitor the evolution of the use of the French language - a monitoring scheme whose interpretations sometimes differ widely but which remains highly dependent on census data availability.

In Quebec, the political use of ethnic categories is linked to the history of nationalism and immigration. To understand this history, a distinction must first be made between ethnic nationalism based on the cultural notion of the nation, which is exclusive, and civic nationalism based on the notion of an inclusive political community (Bouchard 2001; Canet 2003). Most authors divide the history of Quebec

\footnotetext{
${ }^{1}$ See Simon (1997), Kertzer and Ariel (2002), Szreter et al. (2004), Rallu et al. (2006).

${ }^{2}$ See Chap, 1.

${ }^{3}$ The notion of francophone is discussed later.

V. Piché $(\square)$

Oppenheimer Chair in Public International Law, McGill University and Honorary, University of Montreal, Melrose 2249, H4A 2R7 Montreal, Canada

e-mail: v-pic@hotmail.com
} 
nationalism into three periods: (1) 1800-1840, a period of inclusive civic nationalism; (2) 1840-1960, the quintessential period of ethnic nationalism for survival; and (3) since 1960, a period in which inclusive civic nationalism returned and dominated. ${ }^{4}$

Extending this periodization, we suggest four phases that constitute the periods in which the use of ethnic and language categories have changed significantly. The first phase, prior to 1860 , was a period characterized by the notion of 'peoples' rather than ethnicities. Numbers were indeed very important but were basically related to majority-minority relations and the struggle for political representation. In this period, Canadian immigration took place in an imperial and colonial context, marked by a significant flow of British immigrants, especially beginning in 1815 . This imperial context provided the British with particular advantages that were unavailable to other Europeans, and Francophones were therefore excluded from the imperial logic (Ramirez 2001). In fact, the ethnic category only appeared as such in the next phase (1871 census). We will therefore not focus on this first period, which has been characterized as one of political and civic nationalism (Balthazar 1986; Canet 2003). This characterization is important within the context of the current debates that oppose the tenets of civic nationalism and those of ethnic nationalism - an issue that will be revisited in the conclusion.

This chapter will thus examine the three subsequent phases. In brief, the second phase (1860-1960) was one in which ethnic nationalism and the notion of survival were dominant. In the third period (1960-1990), language categories began to emerge alongside ethnic ones. Though they broadened the Francophone category, they remained based on indicators similar to those of ethnic categories such as mother tongue or the language spoken at home. The other (allophone) category also appeared at this time as a Francophone-Anglophone integration issue from a statistical and political perspective. The last period, beginning in 1990, is characterized by the re-definitions of identity that have emerged as a result of increasingly diverse immigration and the development of a relative consensus on the need to re-examine nationalism from a more civic inclusive standpoint. A new category, common public language, therefore tended to replace standard language categories. However, ethnic nationalism is still very much alive and, as we will see, debates are still raging with respect to the choice of language categories and whether or not they should contain an ethnic dimension.

\subsection{Ethnic Categories and Survival: 1860-1960}

Throughout the period, the political use of ethnic categories was intimately related to immigration. Two regimes characterize twentieth century immigration in Canada. The first one, which occurs during the period examined here, has been qualified as racist and assimilationist (Piché 2003). From a purely quantitative perspective, immigration was characterized by highs and lows. A first sub-period (1880-1920)

\footnotetext{
${ }^{4}$ According to Bourque (2003: 9), this periodization reflects the basic theoretical and empirical writings on the notion of nation. Canet (2003: 135) bases his categorizations on Balthazar (1986) and Rioux (1977), among others.
} 
was marked by significant migration beginning in the 1880s and constitutes what is considered to be the first massive wave of migration. It was a time of economic upswing in the manufacturing industry, whose production increased until the 1930s (Elliott 1979) and during which land colonization projects in the West were introduced (Burnet and Palmer 1991; Labelle et al. 1979).

In the wake of the intense official recruitment campaigns conducted outside Great Britain in continental Europe, the importance of the British group diminished as compared to that of other Europeans. In Quebec, the effect of the recruitment policy on ethnic composition was obvious in the shifts that took place between the 1901 and 1921 censuses. The British group shrunk from $18 \%$ in 1901 to $15 \%$ in 1921, and the non-British and non-French group grew from 2 to $5 \%$ (Piché 2003). Several new groups from continental Europe arrived in Quebec but their weight remained relatively small, contrary to what was happening in Western Canada.

There was less migration in 1921-1930, and, in 1931-1950, immigration practically stopped, especially due to three factors: the impacts of WWI, the 1918-1922 economic slowdown and the significant postwar anti-immigration sentiment that was sweeping Canada. It was a time in which the nativist trend was violently expressed. According to Burnet and Palmer (1991: 43), Canada was sufficiently settled, did not require new immigrants and could not absorb additional entrants, especially those who were from outside Great Britain. Certain religious sects, including the Mennonites, Hutterites and Doukhobors were not allowed in Canada (Burnet and Palmer 1991). For other reasons, unions would also jump on the bandwagon, requiring better working conditions over the recruitment of low-cost, strikebreaking immigrant labour (Labelle et al. 1979: 20). The government therefore restricted immigration, establishing a list of desirable and non-desirable countries (Labelle et al. 1983). Black and Asian (especially Chinese) immigration was banned.

During this period, the Quebec government intervened very little in terms of immigration even though the Canadian confederation allows for shared jurisdiction between Canada and the provinces. It was a period in which Quebec frowned upon immigration for historical reasons arising out of French-English conflicts. Immigration was perceived as negative, and people were wary of the Canadian immigration policy that gave preference to the British and which was seen as a strategy to undermine French Canadian majority (Labelle et al. 1979; Linteau et al. 1989: tome 1, 44-45). ${ }^{5}$ According to Juteau (1999: 65-69), in this particular period, the federal state was seen as the instrument of the Anglo-Canadian majority, controlling immigration issues. Up until WWII, federal policies sought to reproduce the existing social order and promote Anglo-conformity.

From an integration perspective, Canada's assimilationist solution was not wellreceived in Quebec, where the presence of a double majority-minority constituted exceptional circumstances. Ethnic duality made assimilation into a single group highly problematic. As a result, the integration model that was set out was based on

\footnotetext{
${ }^{5}$ The essay that most extensively develops the thesis of immigration as a plot to undermine the French Canadian majority is (Bouthillier 1997).
} 
a separate development strategy characterized by segregated institutions based on ethnicity and religion (Linteau et al. 1989: tome 1, 63).

It was the golden age of ethnic statistics in Canada and Quebec. Census data and ethnic categories served to fuel two major questions in Quebec. The first had to do with the proportion of French Canadians in Canada and went unresolved as French Canadians became a small minority in Canada and Quebec's national weight continued to wane to reach less than $30 \%$ by the end of the period (1961). The second concern pertained to the proportion of French Canadians within Quebec - an issue that would develop further in the next two periods - and was considered to be more or less resolved in light of the revanche des berceaux [cradles' revenge] ${ }^{6}$ phenomenon. Both preoccupations were fed by ethnic nationalism that defined us as Canadians of French origin. In sum, it was a period in which ethnic relations were essentially driven by the notion of ethnic duality.

\subsection{Ethnic and Language Categories in the Context of Catching-up: 1960-1990}

After WWII, a new immigration policy was implemented as a result of the economic and political transformations that were affecting most industrialized societies (Simmons 1999). However, two basic principles remained unchanged: a political one affirming national sovereignty in immigration matters and an economic one that took a more systematic approach to linking immigration and national needs and especially labour requirements. However, the mechanisms to meet these needs changed radically. Ethnic preference criteria were replaced by professional qualification criteria (human capital), and the 'laissez-faire' immigrant integration policy was abandoned in favour of an explicit government integration program, which would come to be known as multiculturalism in Canada and interculturalism in Quebec (Juteau et al. 1998).

As in the past, policy changes led to variations in immigration origins (Piché 2003), and immigration became more diverse in Canada and Quebec. In fact, this diversity would continue to increase up until today. These transformations were reflected in Quebec's ethnic structure at the time, as the others category increased significantly from $5.8 \%$ in 1951 to over $20 \%$ in 1991 (Piché 2007).

Quebec only began to take a serious interest in immigration in the current period. Beginning in the 1950s and 1960s, Quebec demography underwent considerable changes, and the secular reproduction mechanism of the French-speaking group (strong natural growth) could no longer maintain the demolinguistic balance that, up until then, had been considered acceptable: more or less $80 \%$ Francophones and $20 \%$ Anglophones and allophones. Demolinguistic projections showed that the relative importance of the Francophone group would shrink significantly if nothing

${ }^{6} \mathrm{~A}$ revenge that lies more in myth than in reality (Marcoux 2010). 
was done to incite immigrants to integrate the Francophone group (Charbonneau et al. 1970). In addition, the 1961 census sent shockwaves through Quebec when it brought to light the vast socio-economic inequalities between linguistic groups, putting Francophones at the bottom of the ladder (Monière 1977: 327; Linteau et al. 1989: tome 2, 205-206). It was this convergence of the economic and ethnic stratification that led to the notion of ethnic class (Dofny and Rioux 1962). ${ }^{7}$

With regards to the integration component of the immigration policy, Quebec was uncomfortable with the multicultural approach implemented by the federal government in the early 1970s. The province openly criticized the model and tried to replace it with cultural convergence and interculturalism (Helly 2000). Multiculturalism continued to be seen as a federal strategy to drown the French Canadian group in the Canadian mosaic, while interculturalism asserted Quebec's Francophone character and invited all groups to fully take part in the collective project (Rocher et al. 2007: 49; Bouchard 2012).

As long as concerns were focussed on ethnicity and the Francophone question blended into the ethnic issue, indicators based on ethnic categories fulfilled their social and political monitoring function, namely to follow the evolution of Anglophone majority/Francophone minority relations in Canada and Francophone majority/Anglophone minority relations in Quebec. But two major changes would come to weaken this quasi-secular perspective. The first arose in the 1960s-1970s with the project, led by the new governing classes, to modernize Quebec. With its universalistic objectives, the project was at odds with the ethnic reference (Rudin 2001). Though the French Canadians became Francophone 'Québécois' in the nationalist discourse, several analysts continued to see in this new terminology a reference to the French Canadian group (Salée 2001; Robin 1996). The second major change occurred with the emergence of pluralism and the need to redefine the notion of $u s$ to account for the increasing diversity of Quebec society, shaped by the last 30 years of immigration (Piché 2002). In addition, Quebec began to take proactive immigration actions through selection and integration policies to preserve the importance of the French language. Several voices began advocating the need to move beyond ethnic nationalism through an approach based on civic citizenship (Bibeau 2000; Bouchard 2001).

The ethnic categories of the census became increasingly irrelevant to this new twist in the political debate. ${ }^{8}$ With self-identification, ethnic origin became more subjective and fluid. In addition, the creation of a Canadian category made it practically impossible to use the responses to this question in analysing the evolution of ethnic groups. Finally, the possibility of recording several ethnic origins beginning in 1981 added still more difficulties in comparing categories with those of earlier censuses. However, these statistical problems did not lead to major offsets since, beginning in the 1970s, they coincided with the gradual replacement of ethnic categories with language categories in the nationalist dis-

\footnotetext{
${ }^{7}$ Putman (2007: 163) suggests that diversity produces more negative effects when ethnic divisions coincide with economic ones.

${ }^{8}$ For a critical analysis of census ethnic categories, see Simon (1997) and Rallu et al. (2006).
} 
course. From then on, monitoring focussed on the state of the French language in Quebec, and several language indicators were advanced to follow the evolution of the use of French. Indicator development therefore went from an ethnic to a linguistic phase. Two particular indicators would dominate demolinguistic debates: those based on mother tongue and those on the language spoken at home. Both are discussed in the next section.

\subsection{Since 1990: Civic or Ethnic Nationalism?}

Beginning in the 1990s, a fourth phase began with the implementation of a new immigration and integration policy focussed on widespread francization. With this policy arose the need for new indicators, since the language indicators that had been used until then were more 'private' and measured the linguistic assimilation process through the notion of language shift (i.e., moving from mother tongue $\mathrm{X}$ to language Y spoken at home). While recognizing the sociological interest in studying linguistic assimilation as so defined, several critics argued the need to introduce new indicators that were more in line with Quebec's integration policy (Béland 2009). Current debates on language indicators, which often give the impression of a 'numbers' war between specialists, must therefore be situated in this context. The next paragraphs will demonstrate that the challenges do not lie in the numbers (or calculation methods) themselves but rather in the choice of indicators and their political and ideological interpretation.

The main question is which indicators for which objectives? The language debate in Quebec essentially rests on the pursuit of two contradictory objectives. The first is directly linked to the concerns of the previous period and the idea of ethnic survival and it aims to propose a social project based on the interests of the 'francophones de souche, ${ }^{10}$ as defined by this group's common history and heritage. This vision of Francophone society in Quebec, which was closely related to the sovereignist political movement, was coined ethnic nationalism. All relevant statistical categories therefore referred to mother tongue and language most often used at home - two indicators with a marked ethnic connotation. This choice of indicator was not politically or ideologically neutral since it made it possible to follow the evolution of the numerical importance of the Francophone group so-defined. The indicators also showed the decline of the French language in Québec and especially on the Island of Montreal at regular intervals (e.g., every 5 years as part of the censuses).

In 2011 (most recent available census), the percentage of Quebecers who spoke French as their mother tongue was less than $80 \%$ (78.1\% compared to $80.9 \%$ in 2001). On the Island of Montreal, the figure was less than $50 \%$. Projections based

\footnotetext{
${ }^{9}$ The setting of historical periods always constitute an artificial exercise and it could be suggested that civic nationalism was not completely absent in other periods, but this needs to be documented.

${ }^{10}$ Souche as in roots, refers to the francophone of French origin.
} 
on language spoken at home (e.g., Termote and Thibeault 2008) were used as a wake-up call in the face of the 'decline' of the French language, especially on the Island of Montreal where the Francophone group would become a minority. Census metropolitan area (CMA) figures indicated higher percentages $(63 \%$ of people listed French as their mother tongue in 2011), but the definition of the geographical area is also an ideological issue. The difference between the two Montreals stems from urban sprawl, since the proportion of Francophones who left the Island of Montreal for the suburbs is greater than that of any other group. In this case, mathematics thus plays a key role, since the Francophone exodus automatically causes the proportion of allophones on the Island of Montreal to rise. In addition, immigration increases the fraction of people who speak a language other than French at home and therefore decreases the proportion of Francophones, especially on the Island of Montreal, where most immigrants choose to live.

At the other end of the spectrum is an approach stipulating that the relevant criteria for language indicator selection can only arise out of the objectives of implemented policies. These objectives were initially set out in the Charter of the French Language in 1977 and then more clearly defined in Quebec's 1992 Policy Statement on Immigration and Integration (Québec 1990). In sum, the objectives define two fundamental trends: a pluralist non-assimilationist integration model and a model to francize immigrants in the public sphere. In keeping with this vision, in as much as the francization policy was explicitly aimed at public communication, language spoken at home, which is a private matter, cannot constitute a relevant indicator to measure the evolution of the French language (Piché 2004; Béland 2009). A public use language indicator became necessary.

In 1997, the Conseil supérieur de la langue française recommended a new indicator based on a series of questions (sample survey) on the use of French in various public spheres. At the time, it was the indicator that yielded the highest percentage of Francophones in Québec (87 \%) and Montreal (78 \% for the CMA and $71 \%$ for the Island). Again, these figures were not surprising since the first two indicators (mother tongue and language spoken at home) did not reveal which language allophones use outside their homes. The Francophone underestimation on the Island is particularly striking, especially when considering the first two indicators. Unfortunately, this type of indicator was used only for 1 year, and the censuses conducted prior to 2001 did not provide information on language use outside the home. Since 2001, the censuses have introduced certain questions on the languages spoken in the workplace. For example, in 2006 in Montreal (CMA), $73 \%$ of people used French most of the time at work (Béland 2008); for 2011, this figure was $71.8 \%$. However for the Island of Montreal, figures are lower: in 2011, only $60 \%$ of the population claimed the use of French at work (language mostly spoken); another $10 \%$ used French and English equally while $14.5 \%$ used French on a regular basis.

In summary, regardless of the demographic tool used (indicator, transfer or projection), the choice of indicator (and its relevance) remains at the heart of every debate. In fact, the choice is ideological and political. Language categories linked to ethnic groups fuel ethnic nationalism. By focussing on the Island of Montreal, these 
categories also emphasize the threat to the French language. However, public language indicators reveal a less menacing situation, even in metropolitan Montreal, and they support the civic approach of the province's immigration and integration policy, as well as the inclusive perspective that stems from the increasing diversity of the population of Quebec.

\subsection{Conclusion}

Indicator production is intimately linked to the political context and therefore meets a social demand based on historical issues. In Quebec, if one excludes a first phase in which the ethnic issue as defined subsequently is absent, we have suggested three other phases with respect to the production of categories and indicators. The first and longest phase was in response to Canada's ethnic duality issue, which monopolized ethnic relations throughout the nineteenth and twentieth centuries. For many years in Quebec, interethnic relations were examined from the dual perspective of French Canadians versus English Canadians and in which French Canadians were the oppressed national minority. There was, in fact, little room for other ethnic minorities given the national minority's concern for its own survival. Also, this view of interethnic relations was linked to the notion that Canada's assimilationist immigration policy posed a threat to the survival of the French Canadian group. This dualistic outlook endured until the 1960s, and indicators served to follow the evolution of the two founding peoples and especially measure French Canadian assimilation outside Quebec. It was the golden age of ethnic statistics based on the census questions on ethnic origin.

With the advent of the modernist and universalistic project implemented in the second half of the twentieth century, a second phase arose along with the need for language rather than ethnic indicators. French Canadians became Francophone 'Québécois', and the pursuit of the demolinguistic balance was rooted in the need to monitor the evolution of French as a national language. In this period, language indicators remained marked by ethnicity given their reliance on criteria pertaining to mother tongue and language spoken at home.

The nationalist discourse of the 1960s continued and even intensified the ethnic approach based on the idea of Quebec as a nation. What changed was the interest in others, since when the discourse assessed other ethnicities, it was mainly to denounce their language choices, which favoured Quebec's Anglophone minority (Piché 1992). The notion of allophone then appeared and became the root of many language conflicts in Quebec, even up until today. The dualistic vision became a triangular one, Francophone-Anglophone-Allophone (Piché 2002).

The increasing diversity of Quebec society made these criteria less and less legitimate in light of their assimilationist underpinnings, since changing one's mother tongue or adopting the use of French at home involves a relatively advanced degree of assimilation. Because Quebec's integration policy was focussed on the public sphere (commerce, schools, labour market, etc.), new indicators were required. A 
third phase therefore emerged and new indicators pertaining to the use of French as a public language were established. The 2001 census responded to this social necessity and introduced questions on languages used in the workplace.

Linguistic debates opposing ethnic and civic nationalists continue to characterize Quebec society. On the one hand, several intellectuals began to reject the old nationalism, which interpreted the history of Quebec through the ethnic and linguistic conflicts and a long series of humiliations experienced by French Canadians following the conquest (the source of these humiliations). This type of nationalism has been coined 'conquêtiste' (Lamoureux 2000) or resentment nationalism (Maclure 2000). For the moment, there seems to be consensus on the fact that this nationalism has fallen out of date, remaining too exclusive, relying on a traumatising view of the past and conveying an ethicizing ideology (Bibeau 2000). ${ }^{11}$

If ethnic nationalism is rejected in the name of increasing diversity of Quebec society, on the other hand, civic nationalism is accused of evacuating the notion of culture in the definition of the nation (Bouchard 2012). Hence, many voices are presently being heard against the civic approach and the pluralistic perspective (Gagnon 2000; Cantin 2002). The civic model has particularly been criticized by Bock-Côté (2007) as ignoring the common history of the French Canadian people and, as one author puts it, the majority guidelines (Lizée 2007). Given that ethnic and linguistic categories will continue to fuel identity politics, it is important to clarify the ideological and political premises that underlie their use in everyday debates.

Open Access This chapter is distributed under the terms of the Creative Commons Attribution Noncommercial License, which permits any noncommercial use, distribution, and reproduction in any medium, provided the original author(s) and source are credited.

\section{References}

Balthazar, L. (1986). Bilan du nationalisme au Québec [Report on Québec nationalism]. Montréal: L'Hexagone.

Béland, P. (2008). Langue et immigration, langue du travail: Éléments d'analyse [Language and immigration, working language: Analytical elements]. Québec: Conseil supérieur de la langue française, Gouvernement du Québec.

Béland, P. (2009). Suivre l'évolution de la situation linguistique au Québec au XXième siècle [Monitoring the evolution of the linguistic status in Québec in the 20th century]. Québec: Conseil supérieur de la langue française, Gouvernement du Québec.

Bibeau, G. (2000). 'Qui a peur des ethnies? Questions (subversives) aux politologues canadiens et québécois' ['Who's afraid of ethnic groups? (Subversive) questions for Québec and Canadian political scientists']. In M. Elbaz \& D. Helly (Eds.), Mondialisation, citoyenneté et multiculturalisme (pp. 171-210). Sainte-Foy/Paris: Les Presses de l'Université Laval \& L'Harmattan, Prisme collection.

\footnotetext{
${ }^{11}$ See Mathieu 2001 for an overview of the debates surrounding the redefining of the Quebec nation.
} 
Bock-Côté, M. (2007). La dénationalisation tranquille [The quiet denationalisation]. Montréal: Boréal.

Bouchard, G. (2001). Ouvrir le cercle de la nation. Activer la cohésion sociale. Réflexions sur le Québec et la diversité' [Opening the circle of the nation, activating social cohesion. Reflections on Québec and diversity]. In M. Sarra-Bournet \& J. Saint-Pierre (Eds.), Les nationalismes au Québec, du XIXe au XXI ${ }^{e}$ siècle (pp. 307-328). Québec: Les Presses de l'Université Laval.

Bouchard, G. (2012). L'interculturalisme: un point de vue québécois. Montréal: Boréal.

Bourque, G. (2003). 'Préface'. In R. Canet (Ed.), Nationalismes et société au Québec (pp. 7-10). Montréal: Athéna.

Bouthillier, G. (1997). L'obsession ethnique [The ethnic obsession]. Montréal: Lanctôt.

Burnet, J., \& Palmer, H. (1991). Coming Canadians: An introduction to a history of Canada's peoples. Ottawa: McClelland and Stewart, in association with the Multiculturalism Program, Dept. of the Secretary of State and the Canadian Government Pub. Centre, Supply and Services Canada.

Canet, R. (2003). Nationalismes et société au Québec [Nationalisms and society in Québec]. Montréal: Athéna.

Cantin, S. (2002). 'Quel avenir pour notre mémoire?' ['What future for our memory?']. Possibles, 26(1), 40-54.

Charbonneau, H., Henripin, J., \& Légaré, J. (1970). 'L'avenir démographique des francophones au Québec et à Montréal, en l'absence de politiques adéquates' ['The demographic future of francophones in Québec and Montréal without adequate policies']. Revue de Géographie de Montréal, XXIV, 2, 199-202.

Dofny, J., \& Rioux, M. (1962). 'Les classes sociales au Canada français' ['Social classes in French Canada']. Revue Française de Sociologie, 3(3), 290-300.

Elliott, J. L. (1979). Canadian immigration: A historical assessment'. In J. L. Elliott (Ed.), Two nations, many cultures: Ethnic groups in Canada (pp. 160-172). Scarborough: Prentice Hall of Canada.

Gagnon, N. (2000). ‘Comment peut-on être Québécois?' ['How to be Québecois']. Recherches sociographiques, XLI, 3, 545-566.

Helly, D. (2000). 'Pourquoi lier citoyenneté, multiculturalisme et mondialisation?' ['Associating citizenship. Multiculturalism and globalization']. In M. Elbaz \& D. Helly (Eds.), Mondialisation, citoyenneté et multiculturalisme (pp. 223-256). Sainte-Foy/Paris: Les Presses de l'Université Laval and L'Harmattan, Prisme collection.

Juteau, D. (1999). L'ethnicité et ses frontières [Ethnicity and its limits]. Montréal: Presses de l'Université de Montréal.

Juteau, D., McAdrew, M., \& Pietrantonio, L. (1998). Multiculturalism à la Canadian and Intégration à la Québécoise. Transcending their Limits'. In R. Bauböck \& J. Rundell (Eds.), Blurred boundaries: Migration, ethnicity, citizenship (pp. 95-110). Aldershot: Ashgate, European Centre Vienna.

Kertzer, D. I., \& Ariel, D. (Eds.). (2002). Census and identity: The politics of race, ethnicity, and language in national censuses. Oxford: Oxford University Press.

Labelle, M., Lemay, D., \& Painchaud, C. (1979). Notes sur l'histoire et les conditions de vie des travailleurs immigrés au Québec [Notes on the history and living conditions of immigrants workers in Québec]. Montréal: CEQ.

Labelle, M., Larose, S., \& Piché, V. (1983). 'Politique d'immigration et immigration en provenance de la Caraïbe Anglophone au Canada et au Québec, 1900-1979' [Anglophone Caribbean immigration policy and immigration in Québec and Canada, 1900-1979]. Canadian Ethnic Studies/Études ethniques au Canada, XV, 2, 1-24.

Lamoureux, D. (2000). 'Citoyenneté, nationalité, culture' [Citizenship, nationality and culture]. In M. Elbaz \& D. Helly (Eds.), Mondialisation, citoyenneté et multiculturalisme (pp. 111-130). Sainte-Foy/Paris: Les Presses de l'Université Laval and L'Harmattan, Prisme collection.

Linteau, P.-A., Durocher, R., \& Robert, J.-C. (1989). Histoire du Québec contemporain [History of contemporary Québec] (Vol. 2). Montréal: Boréal. Boréal compact collection, nos. 14 and 15. 
Lizée, J.-F. (2007). Nous [Us]. Montréal: Boréal

Maclure, J. (2000). Récits identitaires: Le Québec à l'épreuve du pluralisme. Montréal: Éditions Québec/Amérique, Débats collection.

Marcoux, R. (2010, February 1). 'La revanche des berceaux au Québec et la mémoire collective' [Cradles' revenge in Québec and collective memory], Paper presented at INED, Paris.

Mathieu, G. (2001). Qui est Québécois?: synthèse du débat sur la redéfinition de la nation [Who is Québécois? Overview of the debate on redefining the nation] (Vol. 56). Montréal: VLB éditeur, collection 'Études québécoises'.

Monière, D. (1977). Le développement des idéologies au Québec: des origines à nos jours [The development of ideologies in Québec: From its origins to today]. Montréal: Éditions Québec/ Amérique.

Piché, V. (1992). Le discours demo-politique au Québec: inclusion ou exclusion?'. Sociologie et sociétés, XXIV, 2, 143-150.

Piché, V. (2002). Immigration, diversity and ethnic relations in Québec'. Canadian Ethnic Studies/ Études ethniques au Canada, XXXIV, 3, 5-27.

Piché, V. (2003). 'Un siècle d'immigration au Québec: de la peur à l'ouverture' ['A century of immigration in Québec: From fear to openness']. In P. Victor \& B. Le Céline (Eds.), La démographie québécoise. Enjeux du XXIe siècle (pp. 225-263). Montréal: Les Presses de l'Université de Montréal.

Piché, V. (2004). 'Immigration et intégration linguistique: vers un indicateur de réceptivité sociale' [Immigration and linguistic integration: towards a social responsiveness indicator'], Diversité urbaine, 4, 1, Spring: 7-22.

Piché, V. (2007). Immigration et diversité au Québec [Immigration and diversity in Québec], Montréal: synthesis report presented to the Consultation Commission on Accommodation Practices Related to Cultural Differences.

Putman, R. D. (2007). E pluribus unum: Diversity and community in the twenty-first century. The 2006 Johan Skytte Prize Lecture. Scandinavian Political Studies, 30(2), 137-174.

Québec. (1990). Énoncé de politique en matière d'immigration et d'intégration: au Québec, pour bâtir ensemble. Québec: Gouvernement du Québec, Ministère des communautés culturelles et de l'immigration.

Rallu, J.-L., Piché, V., \& Simon, P. (2006). 'Demography and ethnicity: An ambiguous relationship'. In C. Graziella, V. Jacques, \& W. Guillaume (Eds.), Demography: Analysis and synthesis. A treatise in population studies (Vol. 3, pp. 531-549). Waltham: Elsevier, Academic Press.

Ramirez, B. (2001). Crossing the 49th parallel: Migration from Canada to the United States, 1900-1930. Ithaca: Cornell University Press.

Rioux, M. (1977). La question du Québec [The question of Québec]. Montréal: Parti pris.

Robin, R. (1996). 'L'impossible Québec pluriel: la fascination de la "souche" [Impossible plural Québec: the fascination with roots ('souche')]. In M. Elbaz, A. Fortin, \& G. Laforest (Eds.), Les frontières de l'identité. Modernité et postmodernisme au Québec (pp. 295-310). SainteFoy/Paris: Les Presses de l'Université Laval and L'Harmattan.

Rocher, F., Labelle, M., Field A.-M., \& Icart J.-C. (2007). Le concept d'interculturalisme en contexte québécois: généalogie d'une néologisme [The concept of interculturalism in Québec: Genealogy of a neologism]. Report presented to the Consultation Commission on Accommodation Practices Related to Cultural Differences, Montréal.

Rudin, R. (2001). 'L'éclipse du national dans la nouvelle histoire du Québec' [The disappearance of nationality in the new history of QUébec]. In M. Sarra-Bournet \& J. Saint-Pierre (Eds.), Les nationalismes au Québec, du XIX e au XXI siècle (pp. 277-305). Québec: Les Presses de l'Université Laval, Prisme collection.

Salée, D. (2001). 'De l'avenir de l'identité nationale québécoise' [On the future of national identity in Québec]. In J. Maclure \& A.-G. Gagnon (Eds.), Repères en mutation: identité, diversité et citoyenneté dans le Québec contemporain (Vol. 7, pp. 133-164). Montréal: Éditions Québec/ Amérique, Débats collection. 
Simmons, A. B. (1999). Immigrant policy: Imagines futures'. In S. S. Halli \& L. Driedger (Eds.), Immigrant Canada: Demographic, economic, and social challenges (pp. 21-50). Toronto: Toronto University Press.

Simon, P. (1997). 'Les statistiques des origines: 'Race' and ethnicité dans les recensements aux États Unis, Canada et Grande-Bretagne' [Statistics on origins: Race and ethnicity in American, Canadian and British censuses]. Sociétés contemporaines, 26, 11-44.

Szreter, S., Sholkamy, H., \& Dharmalingam, A. (Eds.). (2004). Categories and contexts: Anthropological and historical studies in critical demography. Oxford: Oxford University Press.

Termote, M. (with the collaboration of Thibeault, N). (2008). Nouvelles perspectives démolinguistiques du Québec et de la région de Montréal, 2001-2051 [New demolinguistic perspectives in Québec and the Montréal area]. Québec: Gouvernement du Québec, Conseil de langue française, Study 8. 